\title{
Multivariate state space methods for official statistics and climate modelling
}

Citation for published version (APA):

Schiavoni, C. (2021). Multivariate state space methods for official statistics and climate modelling. [Doctoral Thesis, Maastricht University]. Global Academic Press. https://doi.org/10.26481/dis.20211104cs

Document status and date:

Published: 01/01/2021

DOI:

$10.26481 /$ dis.20211104cs

Document Version:

Publisher's PDF, also known as Version of record

\section{Please check the document version of this publication:}

- A submitted manuscript is the version of the article upon submission and before peer-review. There can be important differences between the submitted version and the official published version of record.

People interested in the research are advised to contact the author for the final version of the publication, or visit the DOI to the publisher's website.

- The final author version and the galley proof are versions of the publication after peer review.

- The final published version features the final layout of the paper including the volume, issue and page numbers.

Link to publication

\footnotetext{
General rights rights.

- You may freely distribute the URL identifying the publication in the public portal. please follow below link for the End User Agreement:

www.umlib.nl/taverne-license

Take down policy

If you believe that this document breaches copyright please contact us at:

repository@maastrichtuniversity.nl

providing details and we will investigate your claim.
}

Copyright and moral rights for the publications made accessible in the public portal are retained by the authors and/or other copyright owners and it is a condition of accessing publications that users recognise and abide by the legal requirements associated with these

- Users may download and print one copy of any publication from the public portal for the purpose of private study or research.

- You may not further distribute the material or use it for any profit-making activity or commercial gain

If the publication is distributed under the terms of Article $25 \mathrm{fa}$ of the Dutch Copyright Act, indicated by the "Taverne" license above, 


\section{Summary}

This thesis explores how state space models, which are a type of econometric models designed to analyse time series data, can be employed to achieve more accurate and realistic estimates of official statistics, and to model and forecast regional concentrations of air pollutants. Specifically, a novel approach is presented, which incorporates survey-based, claimant counts and Google Trends data in order to provide more timely and accurate estimates of Dutch unemployment, over only employing surveybased data. A new method is proposed to model the relationship between the latter and claimant counts data as time-varying, which allows us to promptly tackle changes in such relationship and therefore achieve more realistic real-time estimates of Dutch unemployment. Time-varying relationships can potentially be modelled with other, already existing, econometric techniques, than the one proposed in this thesis, and the reasons why they have not been considered further are here documented. Finally, a novel spatial type of state space model is employed in order to model regional concentrations of nitrogen dioxide $\left(\mathrm{NO}_{2}\right)$ in the Netherlands. The (time-varying) effects on this air pollutant of meteorological conditions, traffic intensity and geographical location of the Dutch regions, are accounted for in the model. The latter is further used to forecast regional $\mathrm{NO}_{2}$ concentrations for different scenarios of traffic intensity, and can therefore be potentially employed for evaluation of pollution-reduction policies. 